\title{
Study on earthquake-induced structural pounding between two adjacent building structures with unequal heights
}

\author{
PEDRO FOLHENTO \\ CONSTRUCT, Faculdade de Engenharia da Universidade do Porto \\ $\mathrm{PhD}$ student at FEUP, Rua Dr. Roberto Frias, s/n 4200-465 Porto \\ PORTUGAL \\ RUI CARNEIRO DE BARROS \\ CONSTRUCT, Faculdade de Engenharia da Universidade do Porto \\ FEUP, Department of Civil Engineering - Structural Division \\ Rua Dr. Roberto Frias, s/n 4200-465 Porto \\ PORTUGAL
}

\author{
MANUEL BRAZ-CÉSAR \\ CONSTRUCT, Instituto Politécnico de Bragança \\ ESTiG, Campus de Santa Apolónia - 5300-253 Bragança \\ PORTUGAL
}

\begin{abstract}
Structural pounding has been found to have a significant influence on the dynamic behavior of building structures under earthquake excitations. This phenomenon is more probable when the buildings have insufficient separation distance and substantial different dynamic properties. In large cities, it is more common for adjacent buildings to have unequal heights, leading to different demands in the structures' stories under earthquake-induced pounding. Hence, in this study five different buildings' configurations with equal or unequal heights and subjected to different ground motions are considered, to study how pounding influences the dynamic behavior of the involved structures. It was found, among other results, that the peak responses tend to suffer amplifications at the stories of the taller building above the height of the shorter building.
\end{abstract}

Key-Words: Building pounding, earthquake-induced structural pounding, unequal heights, impact models, lumped mass models, dynamic behavior.

Received: February 15, 2021. Revised: July 9, 2021. Accepted: July 20, 2021. Published: July 28, 2021.

\section{Introduction}

The phenomenon of structural impacts between adjacent structures is frequently verified in seismic events in metropolises where the construction of buildings is carried out leaving little or no space between them. These impacts of short duration generate large forces, causing significant local damage, whose consequences on the global dynamic behavior of the structures may lead to their collapse. As examples of real seismic events where the phenomenon of impacts was one of the consequences responsible for the loss of human lives and structural damage in buildings, one can highlight, among others, the earthquake in Mexico in 1985 [1], the earthquake in Loma Prieta in 1989 [2], the Tabanli-Van earthquake Turkey in 2011 [3], the earthquake in Christchurch New Zeland in 2011 [4], and the Gorkha earthquake Nepal in 2015 [5]. In the occurrence of seismic events, these impacts become more likely when the dynamic characteristics of adjacent buildings are relatively different. Thus, the resulting out-of-phase vibration of the structures and their displacements exceed the insufficient gap distance left between the structures. It is possible to identify different types of collisions verified between buildings depending on the location of impacts and the characteristics and configurations of the structures [6]. These types essentially refer to impacts between floors, and between floors and columns. Impacts between floors and columns assume that buildings are not aligned in height, whereas impacts between floors may 
occur between structures with equal or unequal heights. Other types of building impacts include collisions between a building and a substantially heavier one, collisions between buildings in series, collisions between plan-asymmetric buildings, causing torsional effects likely to generate eccentric impacts, and impacts between masonry buildings, and between reinforced concrete or steel frame structures filled with masonry walls.

These scenarios cause changes in the global dynamic behavior of the structures, being extremely important to consider in the design phase, and mitigation of the effects of this phenomenon.

Jankowski [7] studied the effect of collisions between floors of buildings of the same height with substantially different masses and stiffnesses. The nonlinear behavior of the structures was considered, verifying that the response of the lighter and more flexible structure is the most affected, suffering permanent deformations, while the stiffer and heavier structure is only slightly influenced by the collisions induced by earthquakes.

Karayannis et al. ([8], [9]) analyzed impacts between floors, and between floors and columns. The authors found that in the case of collisions between floors, the columns near the impact zones suffer increases in ductility demands, which may exceed their respective capacities. In the case of collisions between floors and columns, the authors observed that only the columns in the contact area and above were subjected to significant increases in ductility demands, and the columns under direct impacts are subjected to significant increases in shear forces, exceeding its shear strength.

Abdel Raheem et al. ([10] - [12]), carried out several studies that include collisions between building structures modeled as multiple degrees of freedom systems (MDOFs), viz., mitigation of impacts between buildings with different heights [10], and analysis of impacts between buildings in series with different heights ([11], [12]), analyzing, among other responses, the displacements, accelerations, shear forces and permanent structural damage, as well as the analysis of the separation distance of the buildings, and the effect of seismic excitations characterized by a response spectrum of a certain site. The authors found that collisions amplify the responses of the taller building, viz., displacements in the opposite direction to the impact and shear forces above the top of the lower building. Mate [13] investigated collisions between three building structures in series with elastic behavior using simplified models. In his comparative study, the author used different contact elements and different seismic excitations, analyzing displacements, shear forces, and the energy transfer in collisions during seismic events.

Elwardany et al. [14] investigated the influence of the presence of infill walls on the seismic response of three adjacent buildings with different heights. Considering different configurations for the presence of infill walls, the authors verified that the existence and distribution of these non-structural elements in buildings significantly influence the dynamic behavior of these structures subjected to earthquake-induced impacts. It was also found that although the infill walls can have a positive effect in reducing displacements and, therefore, in reducing the effects of impacts, their distribution in the building structure may have negative consequences. Other recent and relevant studies were carried out comprising the analysis of structural pounding involved responses, viz., on the prediction of critical gap sizes between MDOF systems to avoid collisions ([15], [16]) and on methods to control interstory deflections in MDOF structures [17].

The present numerical study considers two adjacent structures with different dynamic properties under three different real seismic excitations. The heights of the structures will vary and may or may not have the same height. Simplified models of the structures are considered through the use of discrete models programmed in MATLAB [18], that admit lumped masses at the rigid floor levels, which will then be validated with the SAP2000 [19] software. The magnitude of impact forces will be simulated through the use of contact elements. Three recorded accelerograms will be used in the present study, to analyze how different seismic signals affect the dynamic responses with collisions. After performing different simulations, the responses of displacements, interstory drifts, elastic lateral forces, and story shear forces will be examined, to understand the effect of the height variation of buildings under earthquake-induced collisions.

\section{Numerical modeling}

\subsection{Mathematical and computational formulation}

This formulation establishes the equations of motion to be used in the modeling of each building. Thus, the term related to impact forces, resulting from collisions with the adjacent building, is added.

Three-dimensional (3D) buildings are considered as the example shown in Fig. 1a. However, the torsional movement will be neglected, considering only the translational movement in the direction of the seismic excitation. 
It will also be considered the elastic behavior of the structures. Buildings are, therefore, idealized as discrete systems where the masses are concentrated at the floor levels (Fig. 1b), and the floors are considered to be infinitely rigid. These models (lumped mass models or stick models) are widely used in dynamic analyses, especially in analysis involving structural collision problems ([14], [20]), providing acceptable results.

Thus, the dynamic equations of motion for these MDOF systems are obtained through the free-body diagram of the lumped masses involved and carrying out the respective equilibrium conditions, arriving at the following equation

$$
\begin{array}{r}
\underline{\underline{\mathrm{M}}} \underline{\ddot{X}}(t)+\underline{\underline{\mathrm{C}}} \underline{\dot{X}}(t)+\underline{\underline{\mathrm{K}}} \underline{X}(t)= \\
=-F_{P}(t)-\underline{\underline{\mathrm{M}}} \underline{\mathrm{\lambda}}_{\mathrm{g}} \ddot{x}_{\mathrm{g}}(t)
\end{array}
$$

where

$$
\begin{aligned}
& \underline{\underline{\mathrm{M}}}=\left[\begin{array}{ccccc}
m_{1} & 0 & \ldots & 0 & 0 \\
0 & m_{2} & & 0 & 0 \\
\ldots & & \ddots & 0 & 0 \\
0 & 0 & 0 & m_{\mathrm{n}-1} & 0 \\
0 & 0 & 0 & 0 & m_{\mathrm{n}}
\end{array}\right] \\
& \underline{\underline{\mathrm{K}}}=\left[\begin{array}{ccccc}
k_{1}+k_{2} & -k_{2} & \cdots & 0 & 0 \\
-k_{2} & k_{2}+k_{3} & & 0 & 0 \\
\cdots & & \ddots & -k_{\mathrm{n}-1} & 0 \\
0 & 0 & -k_{\mathrm{n}-1} & k_{\mathrm{n}-1}+k_{\mathrm{n}} & -k_{\mathrm{n}} \\
0 & 0 & 0 & -k_{\mathrm{n}} & k_{\mathrm{n}}
\end{array}\right] \text {, } \\
& \underline{\underline{\mathrm{C}}}=a_{0} \underline{\underline{\mathrm{M}}}+a_{1} \underline{\underline{\mathrm{K}}}, \quad \underline{\underline{\lambda}}_{\mathrm{g}}=\{1,1,1, \ldots, 1\}^{\mathrm{T}} \\
& \underline{X}(t)=\left\{\begin{array}{c}
x_{1}(t) \\
x_{1}(t) \\
\ldots \\
x_{n}(t)
\end{array}\right\}, \underline{X}(t)=\left\{\begin{array}{c}
\dot{x}_{1}(t) \\
\dot{x}_{1}(t) \\
\ldots \\
\dot{x}_{n}(t)
\end{array}\right\}, \\
& \underline{\ddot{X}}(t)=\left\{\begin{array}{c}
\ddot{x}_{1}(t) \\
\ddot{x}_{2}(t) \\
\ldots \\
\ddot{x}_{n}(t)
\end{array}\right\}, \underline{F}_{P}(t)=\left\{\begin{array}{c}
f_{P 1}(t) \\
f_{P 2}(t) \\
\ldots \\
f_{P n}(t)
\end{array}\right\}
\end{aligned}
$$

in which $\underline{\underline{\mathrm{M}}}_{(n \times n)}, \underline{\underline{\mathrm{C}}}_{(n \times n)}$, and $\underline{\underline{\mathrm{K}}}_{(n \times n)}$ are, respectively, the mass, damping, and stiffness matrices of a given structure; $\ddot{X}(t), \dot{X}(t), X(t)$, and $F_{P}(t)$ are, respectively, the vector of accelerations, velocities, displacements and impact forces, whose $n$ components correspond to $n$ floors of the respective building; $\lambda_{g}$ is the vector of the location of the seismic forces or accelerations taking into account the respective DOFs, or also called the influence vector coefficients; and $\dot{x}_{g}$ is the horizontal seismic acceleration considered only in the direction where it is intended to study the dynamic behavior of the structure.

The equilibrium equations were established in terms of relative displacements. In addition, the damping matrix is calculated through the linear combination of the mass and stiffness matrix, i.e., using the classical or Rayleigh damping [21], more suitable for civil engineering structures, using the third expression of Equation 2, where $a_{0}$ and $a_{1}$ are the proportionality constants, dependent on the damping ratio and natural frequencies of any two vibration modes. The state-space formulation is used, which is presented below in compact matrix form

$$
\begin{aligned}
& \underline{\dot{Z}}(t)=\left\{\begin{array}{l}
\dot{\dot{X}}(t) \\
\ddot{\ddot{X}}(t)
\end{array}\right\}= \\
& {\left[\begin{array}{cc}
\underline{0} & \underline{\mathrm{I}} \\
-\underline{\underline{\mathrm{M}}}^{-1} \underline{\underline{\mathrm{K}}} & -\underline{\underline{\mathrm{M}}}^{-1} \mathrm{C}
\end{array}\right]\left\{\begin{array}{l}
\underline{X}(t) \\
\dot{\dot{X}}(t)
\end{array}\right\}+\left\{\begin{array}{c}
\underline{0} \\
-\underline{\lambda}_{g}
\end{array}\right\} \ddot{x}_{g}(t)} \\
& \Leftrightarrow \underline{\dot{Z}}(t)_{(2 \mathrm{n} \times 1)}=\underline{A}_{(2 \mathrm{n} \times \mathrm{2n})} \underline{Z}(t)_{(2 \mathrm{n} \times 1)}+\underline{E}_{(2 \mathrm{n} \times 1)} \ddot{x}_{g}(t)_{(1 \times 1)}
\end{aligned}
$$

$$
\begin{aligned}
& {\left[\begin{array}{cc}
\underline{0} & \underline{\underline{\mathrm{I}}} \\
\underline{\mathrm{I}} & \underline{0} \\
-\underline{\underline{\mathrm{M}}} \underline{\underline{\mathrm{K}}} & \underline{\underline{-\mathrm{M}^{-1} \mathrm{~K}}}
\end{array}\right]\left\{\begin{array}{l}
\underline{\underline{X}}(t) \\
\dot{\dot{X}}(t)
\end{array}\right\}+\left\{\begin{array}{c}
\underline{0} \\
-\underline{\lambda}_{g}
\end{array}\right\} \ddot{x}_{g}(t)} \\
& \Leftrightarrow \underline{Y}(t)_{(3 n \times 1)}=\underline{C}_{(3 n \times 2 n)} \underline{Z}(t)_{(2 n \times 1)}+\underline{D}_{(3 n \times 1)} \ddot{x}_{g}(t)_{(1 \times 1)} \\
& \underline{Y}(t)=\left\{\begin{array}{l}
\underline{X}(t) \\
\dot{X}(t) \\
\ddot{X}(t)
\end{array}\right\}=
\end{aligned}
$$

where $\underline{Z}$ is the state vector, having the respective state variables, and $\underline{Y}$ is the output vector of the intended responses; $\underline{\underline{A}}$ is the state matrix, $\underline{\underline{E}}$ the input matrix (otherwise known as $\underline{\underline{B}}$ ), $\underline{\underline{C}}$ is the output matrix or vector, and $\underline{\underline{D}}$ the feedforward or feedthrough matrix or vector; and $\underline{\underline{I}}$ is the identity matrix and $\underline{\underline{0}}$ is the vector or matrix of zeros.

To carry out the proposed simulations taking into account the mathematical formulation presented, it was decided to create algorithms in MATLAB, which will later be validated using SAP2000 software. 
Differential equations are solved in MATLAB using the explicit integration method Runge-Kutta fourthorder with a fixed step of $5 \times 10^{-4} \mathrm{~s}$.

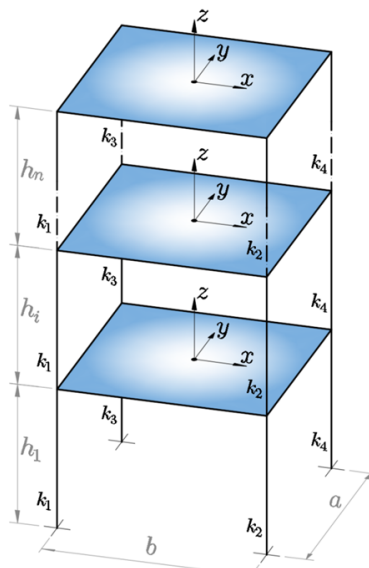

(a) 3D model.

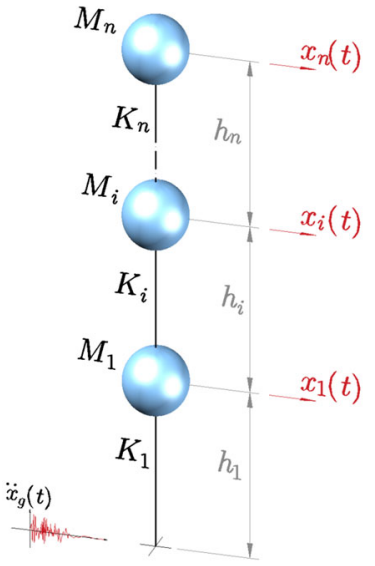

(b) Simplified model.
Figure 1: Building structure's models.

\subsection{Characteristics of buildings to be modeled and configurations considered}

In this numerical study, two adjacent buildings with MDOFs are considered, with each DOF representing a floor $i$ up to a maximum number, $n$, of floors. Each story has $3 m$ of height. Fig. 2a and $2 \mathrm{~b}$ show the plan view of the structures with their respective dimensions.

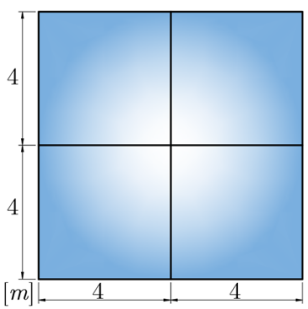

(a) Structure 1 .

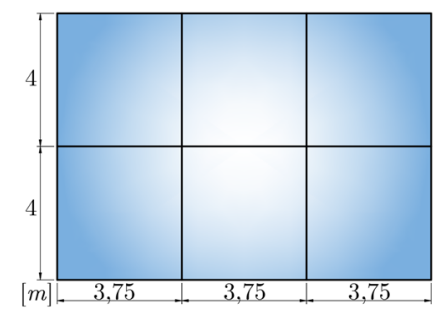

(b) Structure 2
Figure 2: Building structure's plan view.

Table 1 shows the dimensions of the sections of the columns and beams, and the thickness of the slab, with all structural elements in reinforced concrete of class C25/30 (Young's Module: 31GPa) according to Eurocode 2 [22]. Buildings thus have different dynamic properties, with one of the buildings being relatively more flexible and the other more rigid.

The set of these two buildings will have 5 different configurations as shown in Fig. 3, taking into account their variable height (3 to 5 floors), which will enhance the collisions between floors. The buildings with variable height are $2 \mathrm{~cm}$ apart and have different dynamic characteristics to promote their out-of-phase vibration, thus increasing the possibility of structural impacts.
Table 1: Dimensions of structural elements of the structures in the study.

\begin{tabular}{c|cc}
\hline Building & Structure 1 & Structure 2 \\
Dimensions & & \\
\hline Columns $(\boldsymbol{m})$ & $0.30 \times 0.30$ & $0.35 \times 0.35$ \\
Beams $(\boldsymbol{m})$ & $0.30 \times 0.40$ & $0.35 \times 0.45$ \\
Slabs $(\boldsymbol{m})$ & 0.15 & 0.15 \\
\hline
\end{tabular}

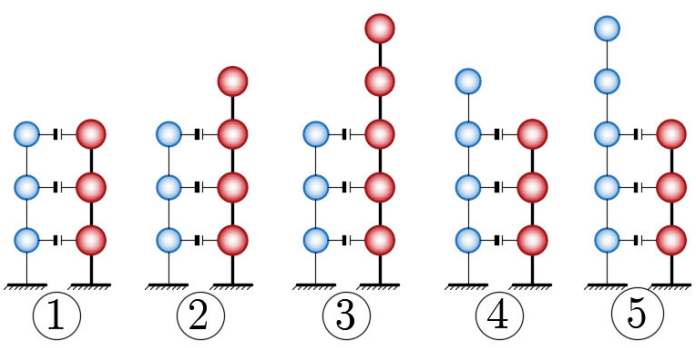

Figure 3: Building structure configurations adopted in this study.

The mass and stiffness (Equation 2) of each floor are easily calculated by considering the simplified lumped mass models. For structure 1 the mass of each floor is $61.6673 \times 10^{3} \mathrm{~kg}$ and of the roof is $54.6542 \times 10^{3} \mathrm{~kg}$. As for the stiffness per floor, the value of $83.7 \times 10^{6} \mathrm{~N} / \mathrm{m}$ was obtained. In turn, for structure 2 , the following mass values were obtained for each floor and roof, respectively, $95.009 \times 10^{3} \mathrm{~kg}$ and $83.8732 \times 10^{3} \mathrm{~kg}$, and for the stiffness of each floor, the value of $206.75 \times 10^{6} \mathrm{~N} / \mathrm{m}$ was obtained.

The mass values were obtained by calculating the mass of the slab and beams of each floor, and by adding half of the mass of the columns above and below the respective floor, and on the last floor only half of the mass of the columns below the respective floor was added. A live load of $2.0 \mathrm{kN} / \mathrm{m}^{2}$ and $0.40 \mathrm{kN} / \mathrm{m}^{2}$ was uniformly distributed over the floors and roof of the structures, respectively. Furthermore, a super dead load of $1.5 \mathrm{kN} / \mathrm{m}^{2}$ was applied evenly distributed over the floors of the structures. According to Eurocode 8 [23], it is mentioned that, for the calculation of the total mass, $50 \%$ of the floor's live load should be considered, and the totality of the live load in the roof.

\subsection{Earthquake excitation signals considered}

The present analysis considers three seismic signals taken from the PEER strong motion database [24] and whose horizontal spectral accelerations are shown in Fig. 4a, and time-histories in Fig. 4b.

The respective characteristics are defined in Table 2 and were obtained with SeismoMatch software [25]. 


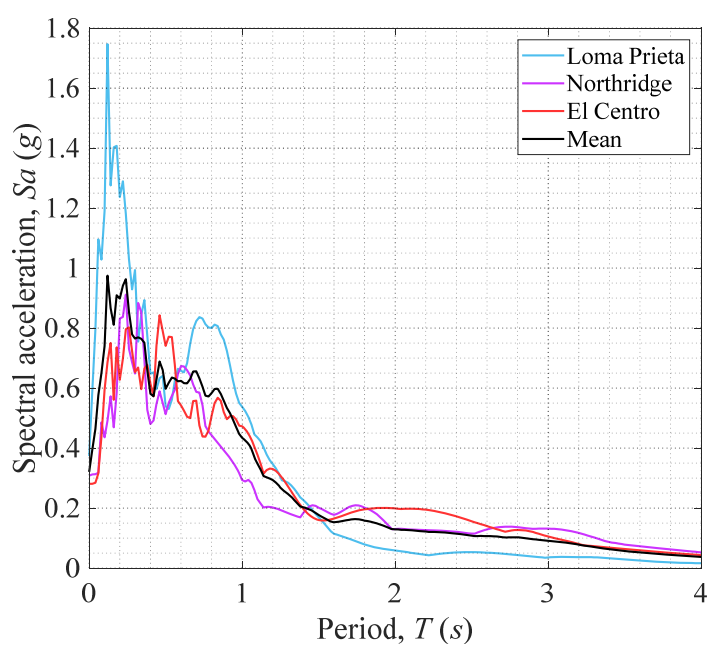

(a) Spectral accelerations.


(b) Signals' accelerations in time-domain.

Figure 4: Seismic signals considered for the present study.

Table 2: Characteristics of the seismic signals considered.

\begin{tabular}{|c|c|c|c|}
\hline Name and station & $\begin{array}{c}\text { Loma Prieta, } \\
1989 \\
\text { WAHO-0 } \\
\text { RSN811 }\end{array}$ & $\begin{array}{c}\text { Northridge, } \\
1994 \\
\text { ArletaNF-360 } \\
\text { RSN949 }\end{array}$ & $\begin{array}{c}\text { El Centro, } \\
1940 \\
\text { Sta9-180 } \\
\text { RSN6 }\end{array}$ \\
\hline Magnitude, $M w$ & 6.93 & 6.69 & 6.95 \\
\hline$P G A(g)$ & 0.373 & 0.308 & 0.281 \\
\hline$P G V(\mathrm{~cm} / \mathrm{s})$ & 27.348 & 22.910 & 30.971 \\
\hline$P G D(\mathrm{~cm})$ & 3.775 & 9.769 & 8.865 \\
\hline $\begin{array}{l}\text { Arias intensity } \\
\qquad(\mathrm{cm} / \mathrm{s})\end{array}$ & 3.704 & 1.172 & 1.556 \\
\hline $\begin{array}{l}\text { Specific energy } \\
\text { density }\left(\mathrm{cm}^{2} / \mathrm{s}\right)\end{array}$ & 859.541 & 1333.391 & 1498.930 \\
\hline $\begin{array}{c}\text { Housner intensity } \\
\text { (cm) }\end{array}$ & 109.134 & 106.582 & 129.234 \\
\hline Dominant period $(s)$ & 0.12 & 0.24 & 0.46 \\
\hline $\begin{array}{c}\text { Significant duration } \\
(s)\end{array}$ & 10.47 & 13.46 & 24.19 \\
\hline
\end{tabular}

The structural systems under study will be submitted to the same signal (neglecting phase difference effects due to seismic waves propagation) with the duration of $25 \mathrm{~s}$ of the seismic signals (see Fig. $4 \mathrm{~b}$ and significant durations in Table 2).

\subsection{Contact model adopted}

For modeling, the magnitude of impact forces, the linear viscoelastic impact model, or the KelvinVoigt model, represented in Fig. 5, is considered. Thus, the impact force present in Equation 1 is calculated according to the following expression [26]

$$
f_{P}(t)= \begin{cases}k_{i m p} \delta(t)+c_{i m p} \dot{\delta}(t), & \text { for } \delta(t)>0 \\ 0 & \text { for } \delta(t) \leq 0\end{cases}
$$

where $k_{i m p}$ is the impact stiffness, $\delta\left(=x_{1}-x_{2}\right.$-Gap) is the interpenetration depth between the structures, defining the impact condition, and $c_{i m p}$ is the impact damping coefficient given by [26]

$$
\begin{gathered}
c_{i m p}=2 \xi_{i m p} \sqrt{k_{i m p} \frac{m_{1} m_{2}}{m_{1}+m_{2}}} \\
\text { where } \xi_{i m p}=\frac{-\ln (C R)}{\sqrt{\pi^{2}+[\ln (C R)]^{2}}}
\end{gathered}
$$

where $C R$ is the restitution coefficient and $\xi_{\text {imp }}$ is the impact damping ratio. However, this model has the limitation of immediately before the separation of the structures, a negative impact force is developed bringing the bodies together instead of naturally separating them, as a result of the uniform dissipation of energy in the two contact periods (approach and restitution) [20]. Thus, the following modification can be applied [27]

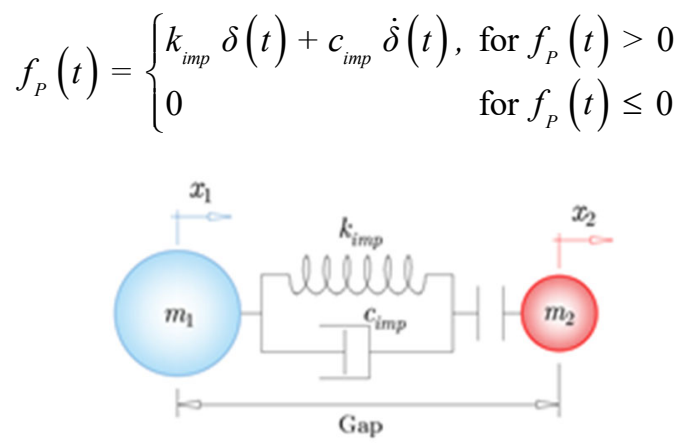

Figure 5: Linear viscoelastic model or Kelvin-Voigt model. 
Since the impacts will be between reinforced concrete structures, it is possible to restrict the $C R$ (i.e., in this case, in between 0.40 and 0.75 ), which can be obtained by the expression proposed by Jankowski [28] based on experimental results,

$$
\begin{aligned}
\mathrm{CR}= & -0.0070 \dot{x}_{i m p}^{3}+0.0696 \dot{x}_{i m p}^{2} \\
& -0.2529 \dot{x}_{i m p}+0.7929
\end{aligned}
$$

depending on the velocity immediately before impact, $\dot{x}_{i m p}$.

Some studies already indicated that the impact stiffness should be of the same order of magnitude as the axial stiffness of the stiffer floor and that this mainly affects the responses of structures in terms of velocities and accelerations, while displacements remain insensitive [29]. Thus, in the present case, the axial stiffness of the stiffer story is $k_{\text {imp }}=4.65 \times 10^{9} \mathrm{~N} / \mathrm{m}$.

It should be referred that to well capture the short duration impact pulses, a sufficiently small step size should be considered in the action of solving the differential equations of motion. In this study, a MATLAB algorithm is modified to consider a smaller step size every time the structures come close to each other, thus extending the condition of pounding to better capture the impacts. Hence, a bigger step size $\left(5 \times 10^{-4} \mathrm{~s}\right)$ is considered in most of the simulation time, whereas for a given value of the relative displacement a smaller step size $\left(5 \times 10^{-5} \mathrm{~s}\right)$ is triggered. This modification will boost the simulation speed and provide more accuracy in the calculation and detection of an impact.

\section{Results and discussion}

\subsection{Numerical validation of the simplified models with SAP2000}

The use of simplified models with rigid floors and the concentrated mass at the level of the floors allows to satisfactorily model the overall dynamic behavior of structures, since these being laterally loaded it is possible to admit the slabs as rigid diaphragms, and the columns as the only contributing elements for the lateral stiffness. Furthermore, it is assumed that the columns are axially rigid and do not suffer axial deformations.

Thus, SAP2000 software was used to create two adjacent buildings under the El Centro earthquake and with the same dynamic and structural properties referred in the previous section, to validate the results obtained with the model in MATLAB.
Contrary to the model developed in MATLAB, the method used to solve the equations of motion in SAP2000 was the build-in direct time integration method, the Newmark solver, with a fixed-step of $5 \times 10^{-4} \mathrm{~s}$.

Only the case of earthquake-induced pounding between the buildings with three stories was used in this validation.

The natural periods obtained with MATLAB for structure 1 were: $T_{1}=0.37128 \mathrm{~s}, T_{2}=0.13385 \mathrm{~s}$ and $T_{3}=0.09397 \mathrm{~s}$; and for structure 2 were: $T_{1}=0.29292 \mathrm{~s}$, $T_{2}=0.10563 \mathrm{~s}$ and $T_{3}=0.074192 \mathrm{~s}$. The natural periods computed with SAP2000 for structure 1 were: $T_{1}=0.376587 \mathrm{~s}, T_{2}=0.135767 \mathrm{~s}$ and $T_{3}=0.095314 \mathrm{~s}$, and for structure 2 were: $T_{1}=0.298619 \mathrm{~s}, T_{2}=0.107715 \mathrm{~s}$ and $T_{3}=0.075678 \mathrm{~s}$.

Fig. 6 and Fig. 7 show the comparison between the results of the two models in terms of displacements and pounding forces.
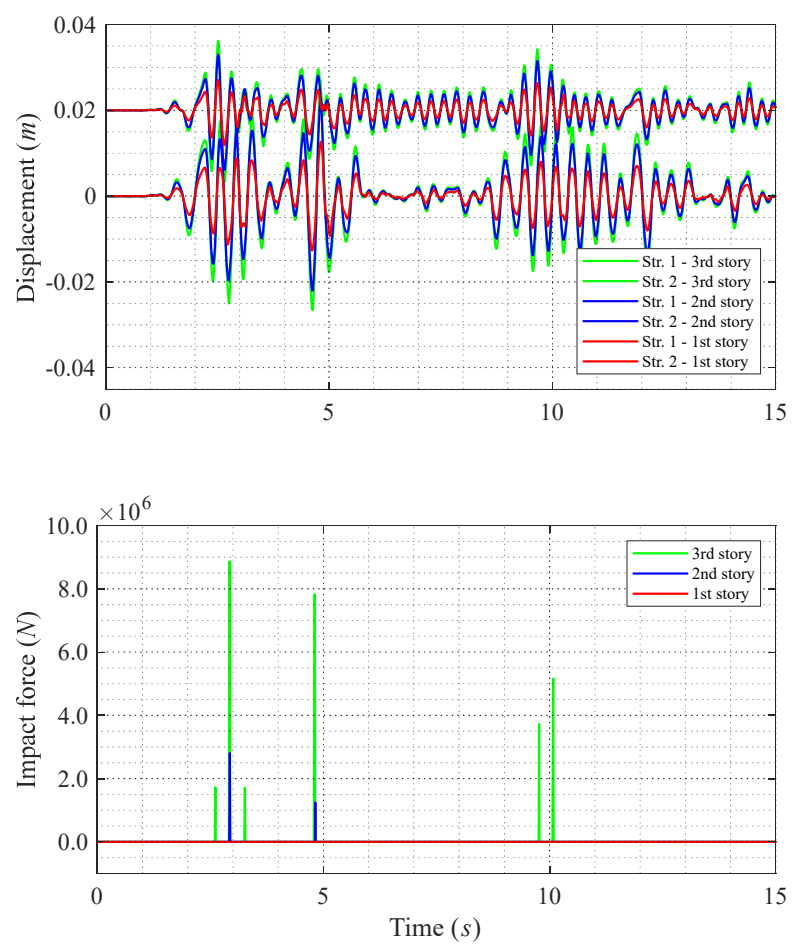

Figure 6: Results obtained with the simplified model programmed in MATLAB software.

From the results obtained it is possible to see that there is good agreement between the two modeling approaches. The natural periods are practically the same, the displacement histories present root mean square errors in the order of $0.1 \%$, and the impacts occur practically at the same time.

However the magnitude of the impacts differs, since SAP2000 does not explicitly possess the KelvinVoigt model as a gap element. 



Figure 7: Results obtained with the finite element model in SAP2000.

Associated with the gap element in SAP2000 there is a spring that must have a value, for the stiffness to be high enough to transmit the impact forces when the gap closes.

The impact forces are then computed using a linear link element with elastic and dissipative properties (respectively, a spring and a damper element in parallel). The impact stiffness value is the same as the one used in the previous section. The impact damping ratio, however, that depends on the $C R$ was not computed using the $C R$ value calculated by Equation 9, but by setting it to a constant value of 0.65 , and then applying Equation 7 to compute the impact damping coefficient.

Fig. 8 presents the contour plots of the colliding structures at the moment immediately after the impact at 3.0s.

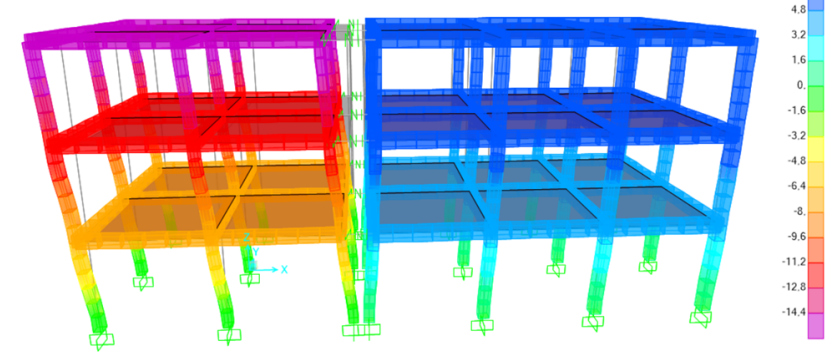

Figure 8: Deformed structures after the impact at $3.0 s$ (SAP2000 results).

\subsection{Different building configurations}

In this subsection, the results regarding the different building configurations under the three seismic signals considered will be presented to understand how structural pounding influences adjacent buildings that have different heights.

The results will be mainly discussed in terms of story displacements, interstory drifts, elastic lateral forces, and shear story forces, by comparing the cases with and without pounding.

The fundamental periods of each structure considered are presented in Table 3.

Table 3: Fundamental periods of each structure

\begin{tabular}{c|cc}
\hline Building & Structure 1 & Structure 2 \\
Stories & & \\
\hline $\mathbf{3}$ & 0.37128 & 0.29292 \\
$\mathbf{4}$ & 0.47897 & 0.37797 \\
$\mathbf{5}$ & 0.58700 & 0.46328 \\
\hline
\end{tabular}

Tables 4 to 6 present the peak responses in terms of absolute interstory drifts and lateral elastic forces per story of the different building configurations, respectively, under the El Centro, Loma Prieta, and Northridge earthquakes. Due to the large amount of data, the results concerning the peak story displacements and peak story shear forces will be omitted from the tabled results, although the discussion will address these results.

It should be pointed out that the lateral forces present positive and negative signs (as the story displacements - not presented) to define whether the force is developed in the inbound or rebound direction, based on the location of the impacts. Hence, and as can be verified in Figures 6 and 7, for structure 1 the inbound direction is the positive one, and the rebound direction is the negative one. Conversely, for structure 2 the inbound direction is the negative one, and the rebound direction is the positive one.

In general, relative story displacements suffer reductions due to structural pounding, mostly in the inbound direction where mutual building blocking happens. However, this reduction is not beneficial since it is tacitly known that the impact forces will cause substantial damage and influence the dynamic behavior in different ways, such as the increases in the interstory drift, lateral forces, story shear forces, and floor accelerations.

The analysis revealed that configuration 2, presented no impacts regardless of the seismic signal, due to the structures' fundamental periods having nearly the same natural periods (see Table 3 ), vibrating almost in-phase. 
Table 4: Results for El Centro earthquake.

\begin{tabular}{|c|c|c|c|c|c|c|c|c|}
\hline \multicolumn{9}{|c|}{ Peak responses } \\
\hline \multirow{2}{*}{\multicolumn{3}{|c|}{ Scenario }} & \multicolumn{2}{|c|}{ Structure 1} & \multicolumn{2}{|c|}{ Structure 2} & \multirow{5}{*}{$\begin{array}{c}\text { Imp. } \\
\text { Force } \\
{[N]}\end{array}$} & \multirow{2}{*}{$\begin{array}{r}N^{\circ} o \\
\text { imp }\end{array}$} \\
\hline & & & $\begin{array}{c}\text { Drift } \\
{[m]}\end{array}$ & $\operatorname{LEF}[N]$ & $\begin{array}{c}\text { Drift } \\
{[\boldsymbol{m}]} \\
\end{array}$ & LEF $[N]$ & & \\
\hline & \multirow{3}{*}{$\begin{array}{l}\text { w/o } \\
\text { imp }\end{array}$} & $S 1$ & 0.0134 & $-3.13 E+05$ & 0.0083 & $-4.80 \mathrm{E}+05$ & & \\
\hline & & $S 2$ & 0.0106 & $-4.37 \mathrm{E}+05$ & 0.0061 & $-6.44 \mathrm{E}+05$ & & \\
\hline & & $S 3$ & 0.0056 & $4.72 \mathrm{E}+05$ & 0.0033 & $6.78 \mathrm{E}+05$ & & \\
\hline$C$ & & $S 1$ & $\begin{array}{c}0.0127 \\
(5 \%)\end{array}$ & $\begin{array}{c}4.39 \mathrm{E}+05 \\
(-29 \%)\end{array}$ & $\begin{array}{c}0.0081 \\
(3 \%)\end{array}$ & $\begin{array}{c}-5.90 \mathrm{E}+05 \\
(-19 \%)\end{array}$ & 0 & 0 \\
\hline & & $S 2$ & 0.0099 & $6.94 \mathrm{E}+05$ & 0.0060 & $-6.46 \mathrm{E}+05$ & $2.85 \mathrm{E}+06$ & 2 \\
\hline & imp & & $(7 \%)$ & $(-37 \%)$ & $(2 \%)$ & $(0 \%)$ & & \\
\hline & & $S 3$ & 0.0057 & $-4.74 \mathrm{E}+05$ & 0.0033 & $6.78 \mathrm{E}+05$ & $8.96 \mathrm{E}+06$ & 6 \\
\hline & & & $(-1 \%)$ & $(0 \%)$ & $(-1 \%)$ & $(0 \%)$ & & \\
\hline & & SI & 0.0134 & $-3.13 \mathrm{E}+05$ & 0.0108 & $-4.31 \mathrm{E}+05$ & & \\
\hline & w/o & $S 2$ & 0.0106 & $-4.37 \mathrm{E}+05$ & 0.0093 & $-5.72 \mathrm{E}+05$ & & \\
\hline & imp & $S 3$ & 0.0056 & $4.72 \mathrm{E}+05$ & 0.0069 & $7.00 \mathrm{E}+05$ & & \\
\hline & & S4 & & & 0.0035 & $-7.29 \mathrm{E}+05$ & & \\
\hline & & $S 1$ & 0.0134 & $-3.13 \mathrm{E}+05$ & 0.0108 & $-4.31 \mathrm{E}+05$ & 0 & 0 \\
\hline C & & & $(0 \%)$ & $(0 \%)$ & $(0 \%)$ & $(0 \%)$ & & \\
\hline 2 & & $S 2$ & 0.0106 & $-4.37 \mathrm{E}+05$ & 0.0093 & $-5.72 \mathrm{E}+05$ & 0 & 0 \\
\hline & & & $(0 \%)$ & $(0 \%)$ & $(0 \%)$ & $(0 \%)$ & & \\
\hline & $\begin{array}{l}\text { W/ } \\
\text { imp }\end{array}$ & $S 3$ & 0.0056 & $4.72 \mathrm{E}+05$ & 0.0069 & $7.00 \mathrm{E}+05$ & 0 & 0 \\
\hline & & & $(0 \%)$ & $(0 \%)$ & $(0 \%)$ & $(0 \%)$ & & \\
\hline & & $S 4$ & & & 0.0035 & $-7.29 \mathrm{E}+05$ & & \\
\hline & & & & & $(0 \%)$ & $(0 \%)$ & & \\
\hline \multirow{15}{*}{$\begin{array}{l}C \\
3\end{array}$} & & $S 1$ & 0.0134 & $-3.13 \mathrm{E}+05$ & 0.0170 & $-3.98 \mathrm{E}+05$ & & \\
\hline & & $S 2$ & 0.0106 & $-4.37 \mathrm{E}+05$ & 0.0151 & $-6.98 \mathrm{E}+05$ & & \\
\hline & W/o & $S 3$ & 0.0056 & $4.72 \mathrm{E}+05$ & 0.0118 & $-8.78 \mathrm{E}+05$ & & \\
\hline & & S4 & & & 0.0081 & $-8.69 \mathrm{E}+05$ & & \\
\hline & & S5 & & & 0.0041 & $-8.45 \mathrm{E}+05$ & & \\
\hline & & $S I$ & 0.0118 & $-7.45 \mathrm{E}+05$ & 0.0173 & $-7.79 \mathrm{E}+05$ & 0 & 0 \\
\hline & & & $(13 \%)$ & $(-58 \%)$ & $(-1 \%)$ & $(-49 \%)$ & & \\
\hline & & $S 2$ & 0.0098 & $5.93 \mathrm{E}+05$ & 0.0142 & $-1.22 \mathrm{E}+06$ & $1.18 \mathrm{E}+05$ & 1 \\
\hline & & & $(8 \%)$ & $(-26 \%)$ & $(7 \%)$ & $(-43 \%)$ & & \\
\hline & $\mathrm{w} /$ & $S 3$ & 0.0114 & $-9.56 \mathrm{E}+05$ & 0.0128 & $-1.27 \mathrm{E}+06$ & $1.31 \mathrm{E}+07$ & 8 \\
\hline & imp & & $(-51 \%)$ & $(-51 \%)$ & $(-8 \%)$ & $(-31 \%)$ & & \\
\hline & & S4 & & & 0.0106 & $-1.37 \mathrm{E}+06$ & & \\
\hline & & & & & $(-24 \%)$ & $(-36 \%)$ & & \\
\hline & & S5 & & & 0.0055 & $-1.15 \mathrm{E}+06$ & & \\
\hline & & & & & $(-26 \%)$ & $(-26 \%)$ & & \\
\hline \multirow{12}{*}{$\begin{array}{l}C \\
4\end{array}$} & & SI & 0.0209 & $-3.09 \mathrm{E}+05$ & 0.0083 & $-4.80 \mathrm{E}+05$ & & \\
\hline & w/o & $S 2$ & 0.0173 & $-4.93 E+05$ & 0.0061 & $-6.44 \mathrm{E}+05$ & & \\
\hline & imp & $S 3$ & 0.0121 & $-5.35 \mathrm{E}+05$ & 0.0033 & $6.78 \mathrm{E}+05$ & & \\
\hline & & S4 & 0.0063 & $-5.30 \mathrm{E}+05$ & & & & \\
\hline & & SI & 0.0168 & $8.76 \mathrm{E}+05$ & 0.0094 & $1.48 \mathrm{E}+06$ & 0 & 0 \\
\hline & & & $(25 \%)$ & $(-65 \%)$ & $(-11 \%)$ & $(-68 \%)$ & & \\
\hline & & $S 2$ & 0.0150 & $8.21 \mathrm{E}+05$ & 0.0064 & $-1.12 \mathrm{E}+06$ & $1.00 \mathrm{E}+07$ & 3 \\
\hline & $\mathrm{w} /$ & & $(16 \%)$ & $(-40 \%)$ & $(-5 \%)$ & $(-43 \%)$ & & \\
\hline & imp & $S 3$ & 0.0113 & $1.06 \mathrm{E}+06$ & 0.0047 & $-9.81 \mathrm{E}+05$ & $1.88 \mathrm{E}+07$ & 10 \\
\hline & & & $(7 \%)$ & $(-49 \%)$ & $(-31 \%)$ & $(-31 \%)$ & & \\
\hline & & S4 & 0.0131 & $1.10 \mathrm{E}+06$ & & & & \\
\hline & & & $(-52 \%)$ & $(-52 \%)$ & & & & \\
\hline & & $S 1$ & 0.0172 & $-3.13 \mathrm{E}+05$ & 0.0083 & $-4.80 \mathrm{E}+05$ & & \\
\hline & & $S 2$ & 0.0160 & $-3.45 \mathrm{E}+05$ & 0.0061 & $-6.44 \mathrm{E}+05$ & & \\
\hline & w/o & $S 3$ & 0.0133 & $3.50 \mathrm{E}+05$ & 0.0033 & $6.78 \mathrm{E}+05$ & & \\
\hline & & S4 & 0.0093 & $4.01 \mathrm{E}+05$ & & & & \\
\hline & & S5 & 0.0045 & $3.80 \mathrm{E}+05$ & & & & \\
\hline & & SI & 0.0182 & $-5.55 \mathrm{E}+05$ & 0.0076 & $7.86 \mathrm{E}+05$ & 0 & 0 \\
\hline & & & $(-5 \%)$ & $(-44 \%)$ & $(9 \%)$ & $(-39 \%)$ & & \\
\hline 5 & & $S 2$ & 0.0165 & $6.03 \mathrm{E}+05$ & 0.0061 & $-9.11 \mathrm{E}+05$ & $3.44 \mathrm{E}+06$ & 1 \\
\hline & & & $(-3 \%)$ & $(-43 \%)$ & $(-1 \%)$ & $(-29 \%)$ & & \\
\hline & $\mathrm{w} /$ & $S 3$ & 0.0138 & $-8.18 \mathrm{E}+05$ & 0.0048 & $9.84 \mathrm{E}+05$ & $1.32 \mathrm{E}+07$ & 21 \\
\hline & imp & & $(-4 \%)$ & $(-57 \%)$ & $(-31 \%)$ & $(-31 \%)$ & & \\
\hline & & S4 & 0.0132 & $7.67 \mathrm{E}+05$ & & & & \\
\hline & & & $(-30 \%)$ & $(-48 \%)$ & & & & \\
\hline & & S5 & 0.0082 & $6.87 \mathrm{E}+05$ & & & & \\
\hline & & & $(-45 \%)$ & $(-45 \%)$ & & & & \\
\hline
\end{tabular}

Legend: $C$ : Configuration; w/: with; w/o: without; imp: Impact; Si: ith Story; LEF: Lateral elastic force.

Percentages: of decrease concerning the respective case without impacts.
Table 5: Results for Loma Prieta earthquake.

\begin{tabular}{|c|c|c|c|c|c|c|c|c|}
\hline & & & & Pea & respons & & & \\
\hline & & & & eture 1 & & cture 2 & Imp. & \\
\hline & nario & & $\begin{array}{l}\text { Drift } \\
{[m]}\end{array}$ & LEF $[N]$ & $\begin{array}{c}\text { Drift } \\
{[m]}\end{array}$ & LEF $[N]$ & $\begin{array}{c}\text { Force } \\
{[N]}\end{array}$ & imp \\
\hline & & $S I$ & 0.0155 & $4.42 \mathrm{E}+05$ & 0.0124 & $-7.94 \mathrm{E}+05$ & & \\
\hline & W/o & $S 2$ & 0.0136 & $-4.95 \mathrm{E}+05$ & 0.0089 & $-1.02 \mathrm{E}+06$ & & \\
\hline & & S3 & 0.0080 & $-6.67 \mathrm{E}+05$ & 0.0049 & $-1.02 \mathrm{E}+06$ & & \\
\hline C & & SI & 0.0153 & $7.98 \mathrm{E}+05$ & 0.0111 & 7.94E+05 & 0 & 0 \\
\hline & w/ & $S 2$ & 0.0131 & $7.15 \mathrm{E}+05$ & 0.0081 & $-9.53 E+05$ & $5.24 \mathrm{E}+06$ & 4 \\
\hline & imp & & $(4 \%)$ & $(-31 \%)$ & $(10 \%)$ & $(7 \%)$ & & \\
\hline & & $S 3$ & $\begin{array}{c}0.0084 \\
(-5 \%)\end{array}$ & $\begin{array}{c}-7.02 \mathrm{E}+05 \\
(-5 \%)\end{array}$ & $\begin{array}{c}0.0048 \\
(2 \%)\end{array}$ & $\begin{array}{c}-9.99 \mathrm{E}+05 \\
(2 \%)\end{array}$ & $1.33 \mathrm{E}+07$ & 10 \\
\hline & & SI & 0.0155 & $4.42 \mathrm{E}+05$ & 0.0111 & $6.19 \mathrm{E}+05$ & & \\
\hline & $\mathrm{w} / \mathrm{o}$ & $S 2$ & 0.0136 & $-4.95 \mathrm{E}+05$ & 0.0111 & $-7.96 \mathrm{E}+05$ & & \\
\hline & imp & S3 & 0.0080 & $-6.67 \mathrm{E}+05$ & 0.0093 & $-8.83 \mathrm{E}+05$ & & \\
\hline & & S4 & & & 0.0050 & $-1.03 \mathrm{E}+06$ & & \\
\hline$C$ & & $S 1$ & $\begin{array}{c}0.0155 \\
(0 \%)\end{array}$ & $\begin{array}{c}4.42 \mathrm{E}+05 \\
(0 \%)\end{array}$ & $\begin{array}{c}0.0111 \\
(0 \%)\end{array}$ & $\begin{array}{c}6.19 \mathrm{E}+05 \\
(0 \%)\end{array}$ & 0 & 0 \\
\hline 2 & & $S 2$ & 0.0136 & $-4.95 \mathrm{E}+05$ & 0.0111 & $-7.96 \mathrm{E}+05$ & 0 & 0 \\
\hline & & & $(0 \%)$ & $(0 \%)$ & $(0 \%)$ & $(0 \%)$ & & \\
\hline & $\begin{array}{l}\text { w/ } \\
\text { imp }\end{array}$ & $S 3$ & 0.0080 & $-6.67 \mathrm{E}+05$ & 0.0093 & $-8.83 \mathrm{E}+05$ & 0 & 0 \\
\hline & & & & & $(0 \%)$ & $(0 \%)$ & & \\
\hline & & S4 & & & $\begin{array}{c}0.0050 \\
(0 \%)\end{array}$ & $\begin{array}{c}-1.03 \mathrm{E}+06 \\
(0 \%)\end{array}$ & & \\
\hline & & $S 1$ & 0.0155 & $4.42 \mathrm{E}+05$ & 0.0147 & $-5.85 \mathrm{E}+05$ & & \\
\hline & & $S 2$ & 0.0136 & $-4.95 \mathrm{E}+05$ & 0.0119 & $8.10 \mathrm{E}+05$ & & \\
\hline & W/O & $S 3$ & 0.0080 & $-6.67 \mathrm{E}+05$ & 0.0095 & $7.64 \mathrm{E}+05$ & & \\
\hline & & S4 & & & 0.0077 & $7.34 \mathrm{E}+05$ & & \\
\hline & & S5 & & & 0.0044 & $-9.16 \mathrm{E}+05$ & & \\
\hline & & $S I$ & $\begin{array}{l}0.0111 \\
(39 \%)\end{array}$ & $\begin{array}{c}-8.27 \mathrm{E}+05 \\
(-47 \%)\end{array}$ & $\begin{array}{c}0.0144 \\
(2 \%)\end{array}$ & $\begin{array}{c}7.84 \mathrm{E}+05 \\
(-25 \%)\end{array}$ & 0 & 0 \\
\hline $\begin{array}{l}C \\
3\end{array}$ & & $S 2$ & 0.0107 & $6.39 \mathrm{E}+05$ & 0.0117 & $-1.08 \mathrm{E}+06$ & $2.07 \mathrm{E}+06$ & 1 \\
\hline & & & $(27 \%)$ & $(-23 \%)$ & $(2 \%)$ & $(-25 \%)$ & & \\
\hline & w/ & S3 & 0.0088 & $-7.40 \mathrm{E}+05$ & 0.0095 & $-9.86 \mathrm{E}+05$ & $1.37 \mathrm{E}+07$ & 8 \\
\hline & & & $(-10 \%)$ & & $(-1 \%)$ & $(-23 \%)$ & & \\
\hline & & S4 & & & 0.0082 & $-1.10 \mathrm{E}+06$ & & \\
\hline & & & & & $(-6 \%)$ & $(-33 \%)$ & & \\
\hline & & S5 & & & 0.0049 & $-1.01 \mathrm{E}+06$ & & \\
\hline & & & & & $(-9 \%)$ & $(-9 \%)$ & & \\
\hline & & SI & 0.0186 & $3.80 \mathrm{E}+05$ & 0.0124 & $-7.94 \mathrm{E}+05$ & & \\
\hline & w/o & $S 2$ & 0.0144 & $5.67 \mathrm{E}+05$ & 0.0089 & $-1.02 \mathrm{E}+06$ & & \\
\hline & imp & $S 3$ & 0.0094 & $4.39 \mathrm{E}+05$ & 0.0049 & $-1.02 \mathrm{E}+06$ & & \\
\hline & & $S 4$ & 0.0058 & $-4.84 \mathrm{E}+05$ & & & & \\
\hline & & S1 & 0.0156 & $8.94 \mathrm{E}+05$ & 0.0109 & $1.27 \mathrm{E}+06$ & 0 & 0 \\
\hline$C$ & & & $(19 \%)$ & $(-58 \%)$ & $(13 \%)$ & $(-38 \%)$ & & \\
\hline 4 & & $S 2$ & 0.0128 & $6.78 \mathrm{E}+05$ & 0.0079 & $-1.32 \mathrm{E}+06$ & $8.05 \mathrm{E}+06$ & 2 \\
\hline & $\mathrm{w} /$ & & $(13 \%)$ & $(-16 \%)$ & $(13 \%)$ & $(-23 \%)$ & & \\
\hline & imp & S3 & 0.0088 & $-8.28 \mathrm{E}+05$ & 0.0049 & $-1.01 \mathrm{E}+06$ & $1.49 \mathrm{E}+07$ & 14 \\
\hline & & & $(7 \%)$ & $(-47 \%)$ & $(1 \%)$ & $(1 \%)$ & & \\
\hline & & $S 4$ & 0.0105 & $8.77 \mathrm{E}+05$ & & & & \\
\hline & & & $(-45 \%)$ & $(-45 \%)$ & & & & \\
\hline & & $S I$ & 0.0209 & $-2.89 \mathrm{E}+05$ & 0.0124 & $-7.94 \mathrm{E}+05$ & & \\
\hline & & $S 2$ & 0.0202 & $3.95 \mathrm{E}+05$ & 0.0089 & $-1.02 \mathrm{E}+06$ & & \\
\hline & w/o & S3 & 0.0158 & $5.63 \mathrm{E}+05$ & 0.0049 & $-1.02 \mathrm{E}+06$ & & \\
\hline & & $S 4$ & 0.0107 & $4.79 \mathrm{E}+05$ & & & & \\
\hline & & S5 & 0.0060 & $5.03 \mathrm{E}+05$ & & & & \\
\hline & & S1 & 0.0166 & $7.21 \mathrm{E}+05$ & 0.0103 & $1.06 \mathrm{E}+06$ & 0 & 0 \\
\hline & & & $(26 \%)$ & $(-60 \%)$ & $(20 \%)$ & $(-25 \%)$ & & \\
\hline C & & $S 2$ & 0.0113 & $6.83 \mathrm{E}+05$ & 0.0077 & $-8.69 \mathrm{E}+05$ & $9.18 \mathrm{E}+06$ & 1 \\
\hline & & & $(78 \%)$ & $(-42 \%)$ & $(16 \%)$ & $(17 \%)$ & & \\
\hline & $\mathrm{w} /$ & S3 & 0.0118 & $-1.09 \mathrm{E}+06$ & 0.0044 & $-9.19 \mathrm{E}+05$ & $1.79 \mathrm{E}+07$ & 10 \\
\hline & imp & & $(34 \%)$ & $(-48 \%)$ & $(10 \%)$ & $(10 \%)$ & & \\
\hline & & S4 & 0.0161 & $9.14 \mathrm{E}+05$ & & & & \\
\hline & & & $(-34 \%)$ & $(-48 \%)$ & & & & \\
\hline & & S5 & 0.0093 & $7.82 \mathrm{E}+05$ & & & & \\
\hline & & & $(-36 \%)$ & $(-36 \%)$ & & & & \\
\hline
\end{tabular}

Legend: $C$ : Configuration; w/: with; w/o: without; imp: Impact; Si: ith Story; LEF: Lateral elastic force.

Percentages: of decrease concerning the respective case without impacts. 
Table 6: Results for Northridge earthquake.

\begin{tabular}{|c|c|c|c|c|c|c|c|c|}
\hline \multicolumn{9}{|c|}{ Peak responses } \\
\hline \multirow{2}{*}{\multicolumn{3}{|c|}{ Scenario }} & \multicolumn{2}{|c|}{ Structure 1} & \multicolumn{2}{|c|}{ Structure 2} & \multirow{2}{*}{$\begin{array}{c}\text { Imp. } \\
\text { Force } \\
{[N]} \\
\end{array}$} & \multirow{2}{*}{$\begin{array}{l}\mathrm{N}^{\circ} \text { of } \\
\text { imp }\end{array}$} \\
\hline & & & $\begin{array}{l}\text { Drift } \\
{[m]}\end{array}$ & LEF $[N]$ & $\begin{array}{c}\text { Drift } \\
{[m]}\end{array}$ & LEF $[N]$ & & \\
\hline & \multirow{3}{*}{$\begin{array}{l}\text { w/o } \\
\text { imp }\end{array}$} & $S 1$ & 0.0116 & $2.37 \mathrm{E}+05$ & 0.0074 & $-3.64 \mathrm{E}+05$ & & \\
\hline & & $S 2$ & 0.0088 & $3.76 \mathrm{E}+05$ & 0.0058 & $5.74 \mathrm{E}+05$ & & \\
\hline & & $S 3$ & 0.0046 & $3.87 \mathrm{E}+05$ & 0.0030 & $-6.24 E+05$ & & \\
\hline & & $S 1$ & 0.0130 & $6.20 \mathrm{E}+05$ & 0.0073 & $7.03 \mathrm{E}+05$ & 0 & 0 \\
\hline 1 & & & $(-11 \%)$ & $(-62 \%)$ & $(2 \%)$ & $(-48 \%)$ & & \\
\hline & $\mathrm{w} /$ & $S 2$ & 0.0099 & $7.49 \mathrm{E}+05$ & 0.0056 & $-6.63 \mathrm{E}+05$ & $4.01 \mathrm{E}+06$ & 1 \\
\hline & imp & & $(-11 \%)$ & $(-50 \%)$ & $(3 \%)$ & $(-13 \%)$ & & \\
\hline & & $S 3$ & 0.0057 & $4.75 \mathrm{E}+05$ & 0.0029 & $5.98 \mathrm{E}+05$ & $1.01 \mathrm{E}+07$ & 2 \\
\hline & & & $(-19 \%)$ & $(-19 \%)$ & $(4 \%)$ & $(4 \%)$ & & \\
\hline \multirow{10}{*}{$\begin{array}{l}C \\
2\end{array}$} & & $S 1$ & 0.0116 & $2.37 \mathrm{E}+05$ & 0.0088 & $3.14 \mathrm{E}+05$ & & \\
\hline & w/o & $S 2$ & 0.0088 & $3.76 \mathrm{E}+05$ & 0.0074 & $4.94 \mathrm{E}+05$ & & \\
\hline & imp & $S 3$ & 0.0046 & $3.87 \mathrm{E}+05$ & 0.0054 & $5.61 \mathrm{E}+05$ & & \\
\hline & & S4 & & & 0.0028 & $-5.89 \mathrm{E}+05$ & & \\
\hline & & $S 1$ & 0.0116 & $2.37 \mathrm{E}+05$ & 0.0088 & $3.14 \mathrm{E}+05$ & 0 & 0 \\
\hline & & & $(0 \%)$ & $(0 \%)$ & $(0 \%)$ & $(0 \%)$ & & \\
\hline & & $S 2$ & $\begin{array}{c}0.0088 \\
(0 \%)\end{array}$ & $\begin{array}{c}3.76 \mathrm{E}+05 \\
(0 \%)\end{array}$ & $\begin{array}{c}0.0074 \\
(0 \%)\end{array}$ & $\begin{array}{c}4.94 \mathrm{E}+05 \\
(0 \%)\end{array}$ & 0 & 0 \\
\hline & w/ & $S 3$ & 0.0046 & $3.87 \mathrm{E}+05$ & 0.0054 & $5.61 \mathrm{E}+05$ & 0 & 0 \\
\hline & & & $(0 \%)$ & $(0 \%)$ & $(0 \%)$ & $(0 \%)$ & & \\
\hline & & S4 & & & $\begin{array}{c}0.0028 \\
(0 \%)\end{array}$ & $\begin{array}{c}-5.89 \mathrm{E}+05 \\
(0 \%)\end{array}$ & & \\
\hline \multirow{15}{*}{$\begin{array}{l}C \\
3\end{array}$} & & $S 1$ & 0.0116 & $2.37 \mathrm{E}+05$ & 0.0114 & $-3.69 \mathrm{E}+05$ & & \\
\hline & & $S 2$ & 0.0088 & $3.76 \mathrm{E}+05$ & 0.0106 & $-4.62 \mathrm{E}+05$ & & \\
\hline & W/o & $S 3$ & 0.0046 & $3.87 \mathrm{E}+05$ & 0.0087 & $5.43 \mathrm{E}+05$ & & \\
\hline & & S4 & & & 0.0061 & $6.41 \mathrm{E}+05$ & & \\
\hline & & S5 & & & 0.0030 & $6.16 \mathrm{E}+05$ & & \\
\hline & & $S I$ & 0.0128 & $5.42 \mathrm{E}+05$ & 0.0112 & $-4.56 \mathrm{E}+05$ & 0 & 0 \\
\hline & & & $(-9 \%)$ & $(-56 \%)$ & $(2 \%)$ & $(-19 \%)$ & & \\
\hline & & $S 2$ & 0.0101 & $4.98 \mathrm{E}+05$ & 0.0101 & $-7.67 \mathrm{E}+05$ & 0 & 0 \\
\hline & & & $(-12 \%)$ & $(-25 \%)$ & $(5 \%)$ & $(-40 \%)$ & & \\
\hline & $\mathrm{w} /$ & $S 3$ & 0.0062 & $-5.16 \mathrm{E}+05$ & 0.0083 & $-8.14 \mathrm{E}+05$ & $1.01 \mathrm{E}+07$ & 7 \\
\hline & imp & & $(-25 \%)$ & $(-25 \%)$ & $(5 \%)$ & $(-33 \%)$ & & \\
\hline & & $S 4$ & & & 0.0076 & $-9.80 \mathrm{E}+05$ & & \\
\hline & & & & & $(-20 \%)$ & $(-35 \%)$ & & \\
\hline & & S5 & & & 0.0038 & $-7.81 E+05$ & & \\
\hline & & & & & $(-21 \%)$ & $(-21 \%)$ & & \\
\hline \multirow{12}{*}{$\begin{array}{l}C \\
4\end{array}$} & & SI & 0.0136 & $-2.64 \mathrm{E}+05$ & 0.0074 & $-3.64 \mathrm{E}+05$ & & \\
\hline & w/o & $S 2$ & 0.0124 & $-3.08 \mathrm{E}+05$ & 0.0058 & $5.74 \mathrm{E}+05$ & & \\
\hline & imp & $S 3$ & 0.0091 & $3.82 \mathrm{E}+05$ & 0.0030 & $-6.24 \mathrm{E}+05$ & & \\
\hline & & S4 & 0.0045 & $3.80 \mathrm{E}+05$ & & & & \\
\hline & & SI & 0.0118 & $-5.44 \mathrm{E}+05$ & 0.0072 & $1.02 \mathrm{E}+06$ & 0 & 0 \\
\hline & & & $(15 \%)$ & $(-51 \%)$ & $(3 \%)$ & $(-64 \%)$ & & \\
\hline & & $S 2$ & 0.0098 & $5.74 \mathrm{E}+05$ & 0.0057 & $-9.43 E+05$ & $4.13 \mathrm{E}+06$ & 2 \\
\hline & $\mathrm{w} /$ & & $(28 \%)$ & $(-46 \%)$ & $(1 \%)$ & $(-39 \%)$ & & \\
\hline & imp & $S 3$ & 0.0092 & $7.74 \mathrm{E}+05$ & 0.0039 & $-8.11 \mathrm{E}+05$ & $1.23 \mathrm{E}+07$ & 9 \\
\hline & & & $(-1 \%)$ & $(-51 \%)$ & $(-23 \%)$ & $(-23 \%)$ & & \\
\hline & & S4 & 0.0098 & $8.18 \mathrm{E}+05$ & & & & \\
\hline & & & $(-53 \%)$ & $(-53 \%)$ & & & & \\
\hline \multirow{15}{*}{$\begin{array}{l}C \\
5\end{array}$} & & $S 1$ & 0.0213 & $-2.45 \mathrm{E}+05$ & 0.0074 & $-3.64 \mathrm{E}+05$ & & \\
\hline & & $S 2$ & 0.0185 & $3.19 \mathrm{E}+05$ & 0.0058 & $5.74 \mathrm{E}+05$ & & \\
\hline & w/o & $S 3$ & 0.0154 & $-3.89 \mathrm{E}+05$ & 0.0030 & $-6.24 \mathrm{E}+05$ & & \\
\hline & & S4 & 0.0108 & $-4.72 \mathrm{E}+05$ & & & & \\
\hline & & S5 & 0.0051 & $-4.30 \mathrm{E}+05$ & & & & \\
\hline & & SI & 0.0159 & $-8.30 \mathrm{E}+05$ & 0.0085 & $-1.23 \mathrm{E}+06$ & 0 & 0 \\
\hline & & & $(34 \%)$ & $(-70 \%)$ & $(-13 \%)$ & $(-70 \%)$ & & \\
\hline & & $S 2$ & 0.0144 & $6.04 \mathrm{E}+05$ & 0.0065 & $-1.16 \mathrm{E}+06$ & $9.32 \mathrm{E}+06$ & 4 \\
\hline & & & $(29 \%)$ & $(-47 \%)$ & $(-12 \%)$ & $(-51 \%)$ & & \\
\hline & $\mathrm{w} /$ & S3 & 0.0128 & $-1.00 \mathrm{E}+06$ & 0.0048 & $9.82 \mathrm{E}+05$ & $1.59 \mathrm{E}+07$ & 14 \\
\hline & imp & & $(20 \%)$ & $(-61 \%)$ & $(-36 \%)$ & $(-36 \%)$ & & \\
\hline & & S4 & 0.0151 & $7.84 \mathrm{E}+05$ & & & & \\
\hline & & & $(-29 \%)$ & $(-40 \%)$ & & & & \\
\hline & & S5 & 0.0085 & $7.08 \mathrm{E}+05$ & & & & \\
\hline & & & $(-39 \%)$ & $(-39 \%)$ & & & & \\
\hline
\end{tabular}

Legend: $C$ : Configuration; w/: with; w/o: without; imp: Impact; Si: ith Story; LEF: Lateral elastic force.

Percentages: of decrease concerning the respective case without impacts.
Observing the tabulated results presented for the different building configurations and seismic signals, it is possible to conclude that the peak absolute interstory drifts and the peak lateral forces (and also peak story shear forces - not presented) suffer great increases in the stories of the taller building above the shorter building.

Not only amplifications of the interstory drifts, lateral forces, and story shears are always verified in the stories above the level of the top story of the shorter building, but also these peak responses tend to be amplified in the inbound direction when the peak responses without pounding were originally verified in this direction, and changed from the rebound to the inbound direction when the peak responses were originally verified in the rebound direction. This can be proven by the observation of the tabled values of the lateral forces and respective signs. This happens naturally since the shorter building blocks the motion of the tallest building leaving the stories of the taller structure above the height level of the shorter building freely to move by the action of inertia.

Observing configuration 1 (structures with the same height), it can be verified that the flexible structure (structure 1) is more affected by pounding than the stiffer structure (structure 2), being more evident when subjected to the Northridge earthquake.

When structure 2 has more stories, as in the case of configuration 2 or 3, two different outcomes were verified. The first already mentioned was when one story was added (configuration 2), matching the fundamental periods and leading to no impacts. The second is when two stories were added (configuration 3) turning the once stiffer structure (structure 2) into the more flexible one by increasing its fundamental period (see Table 3 ). In comparison with configuration 1 , structure 2 in configuration 3 becomes more susceptible to pounding, while structure 1 generally becomes less affected by pounding, nevertheless presenting great amplification of the peak responses at the top story. Now, observing the configurations when structure 1 has more stories (configurations 4 and 5), structure 1 becomes more flexible, enlarging the difference between the two structures in terms of dynamic properties. Comparing with configuration 1, structure 1 in configurations 4 and 5 suffers reductions in terms of maximum interstory drifts and story shear forces at the stories below the level of the top story of structure 2 . The exception to this is when the structure is subjected to the El Centro earthquake, which has a dominant period closer to the fundamental period of structure 1 in this configuration, which may have caused the slight 
amplification of these peak responses. Nevertheless, lateral forces in structure 1 generally increase when more stories are considered. Structure 2 becomes more affected by pounding in these configurations compared to configuration 1 .

This is only true for the cases where the El Centro and Northridge seismic excitations are considered.Structural pounding was found to have less effect when the structures were subjected to the Loma Prieta earthquake. This is possibly due to its dominant period being less than the fundamental periods of the structures.

To support the previous conclusions the graphs regarding the story shear forces of configurations 1 to 5 are, respectively, presented in Fig. 9 to 13 .

By the observation of Fig. 9, where the structures have the same height, it is possible to see that only the case of structure 1 suffers amplifications of the story shear force due to pounding in the top story, in the rebound direction.

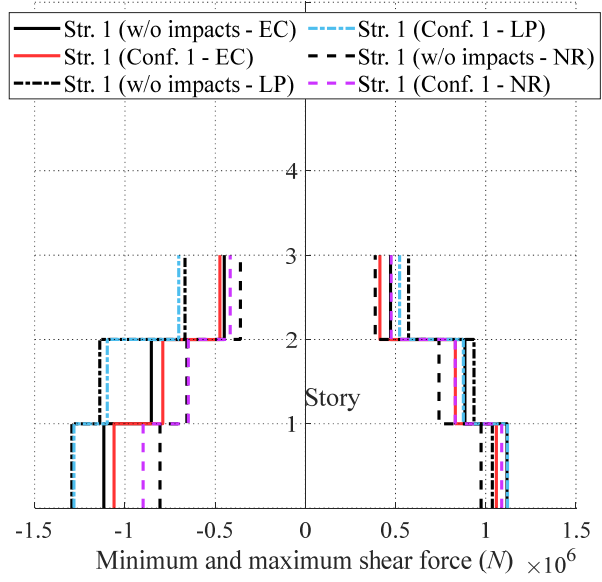

(a) Structure 1.

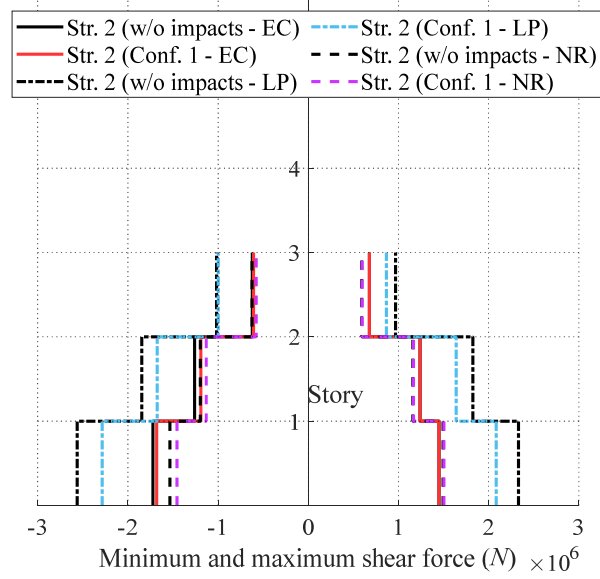

(b) Structure 2.

Figure 9: Story shear forces in the first configuration.
Fig. 10 presents the case previously mentioned where the structures are in phase and thus, suffered no impacts.

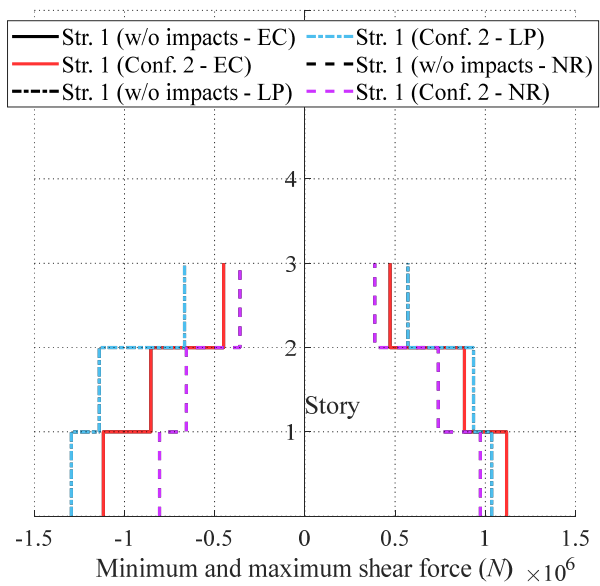

(a) Structure 1 .

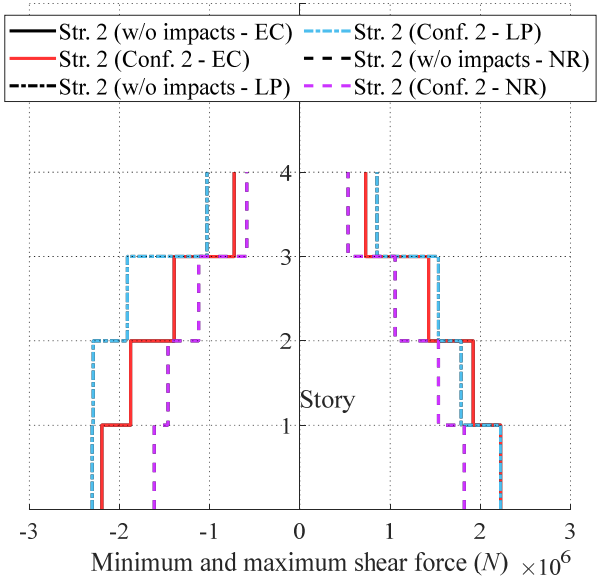

(b) Structure 2

Figure 10: Story shear forces in the second configuration.

Fig. 11 presents the influence of pounding in the top story of structure 1 where significant amplification of the story shear forces can be verified in the rebound direction. Structure 2 also shows some amplification of the shear forces of the stories at and above the top story of the shorter building.

Observing Fig. 12, the peak shear forces at the top story of structure 1 presents increases compared to the case of no pounding, mostly verified in the inbound direction due to the collisions with the shorter building. The shorter building in this configuration also presented amplification of the shear forces at the top story.

Similar conclusions presented for configuration 4 can be withdrawn concerning the case of configuration 5 shown in Fig. 13. 


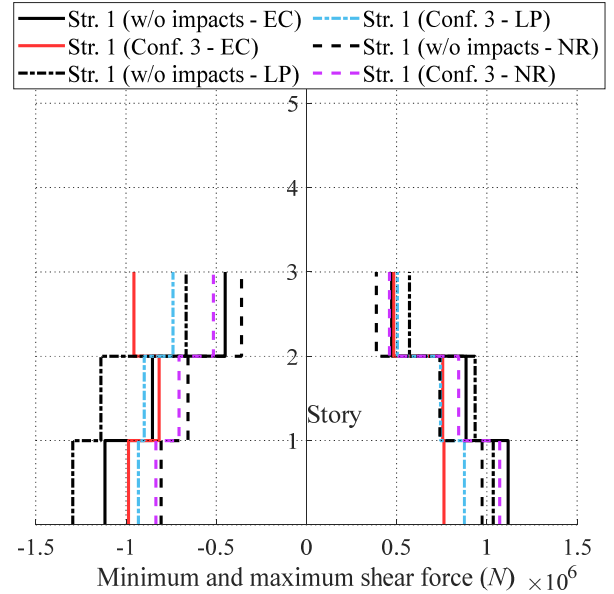

(a) Structure 1.

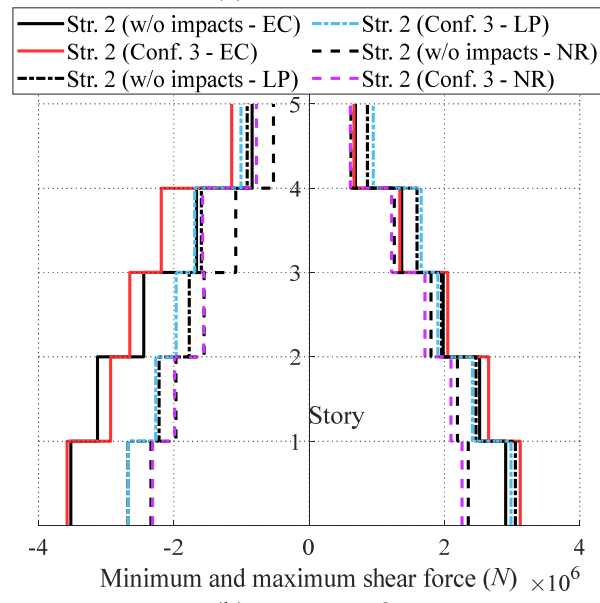

(b) Structure 2.

Figure 11: Story shear forces in the third configuration.

Regarding pounding forces, the number and the maximum intensity of impacts increase for higher stories, and generally increase when the buildings have unequal heights, as can be verified by comparing configuration 1 with the other configurations.

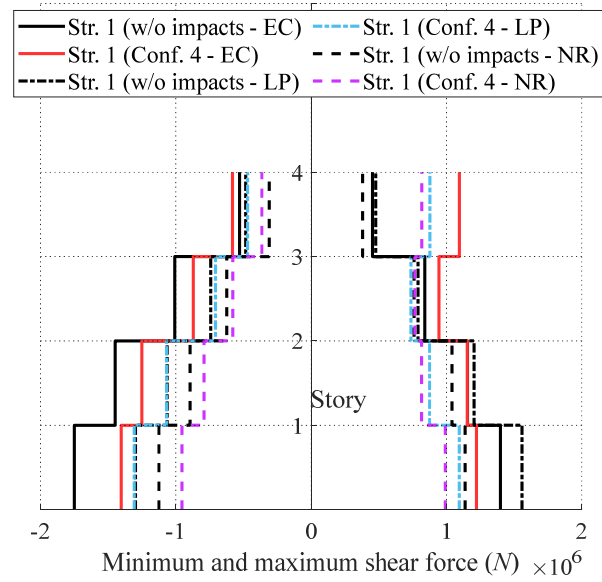

(a) Structure 1.

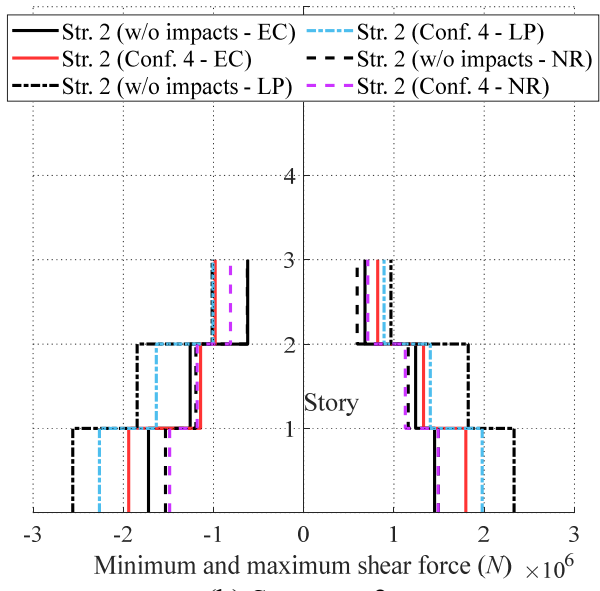

(b) Structure 2.

Figure 12: Story shear forces in the fourth configuration.

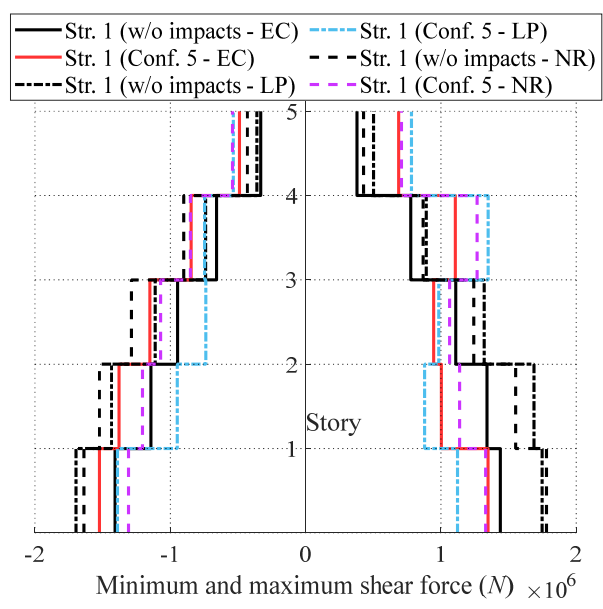

(a) Structure 1



(b) Structure 2.

Figure 13: Story shear forces in the fifth configuration. 


\section{Conclusions}

This investigation intended to study how buildings' configurations with unequal heights and aligned floors behave under earthquake-induced structural pounding. Simplified models were developed and used and further validated with an equivalent finite element model.

Ultimately, it was verified that the peak absolute interstory drifts, lateral elastic forces, and story shear forces suffer great increases in the stories of the taller building above the height of the shorter building.

The peak responses in these stories tend to be amplified in the inbound direction due to building blocking. Conversely, the stories of the taller building below the height of the shorter building tend, in general, to suffer reductions due to pounding.

Structural pounding always increases the peak lateral elastic restoring forces. In general, this increase is more evident when the buildings have unequal heights.

By the observation of the graphs considering the minimum and maximum story shear forces, it is possible to see that in general pounding has more influence in the top story of the shorter building and the stories of the taller building above the shorter building.

It should be referred that the consideration of different earthquakes may lead to different results in terms of peak responses. Seismic excitations naturally have more influence in structures with fundamental periods closer to the dominant period of excitation, which in this case may be reflected on bigger amplification of the peak responses due to pounding, as can be verified when the structures are subjected to the El Centro and Northridge earthquake excitations.

The number and the maximum intensity of impacts increase for higher stories and generally increase when the buildings have unequal heights.

However, this study comprised building structures with elastic behavior, that may overestimate the number and intensity of impacts, and underestimate displacements. Hence, further studies should include non-linear inelastic behavior adapted to the simplified models, and the consideration of seismic excitations representative of a seismic region to account more realistically for the seismic effect.

\section{References:}

[1] M. Degg, "Some implications of the 1985 Mexican earthquake for hazard assessment", Geohazards, Springer, pp. 105-114, 1992.
[2] K. Kasai, and B. Maison, "Building pounding damage during the 1989 Loma Prieta earthquake", Engineering Structures, vol. 19(3), pp. 195-207, 1997.

[3] B. Taskin, A. Sezen, U. Tugsal, e A. Erken, "The aftermath of 2011 Van earthquakes: evaluation of strong motion, geotechnical and structural issues", Bulletin of Earthquake Engineering, vol. 11, pp. 285-312, 2013.

[4] G. Cole, R. Dhakal, e N. Chouw, "Building Pounding Damage Observed in the 2011 Christchurch Earthquake", In Proceedings of the 15th world conference on earthquake engineering. Lisbon, Portugal, 2012.

[5] K. Sharma, L. Deng, e C. Noguez, "Field investigation on the performance of building structures during the April 25, 2015, Gorkha earthquake in Nepal", Engineering Structures, vol. 121, pp. 61-74, 2016.

[6] G. L. Cole, R. P. Dhakal, A. J. Carr and D. K. Bull, "Building pounding state of the art: Identifying structures vulnerable to pounding damage," in New Zealand Society of Earthquake Engineerings (NZSEE) Conference, 26-28 March, Wellington, NZ, 2010.

[7] R. Jankowski, "Earthquake-induced pounding between equal height buildings with substantially different dynamic properties", Engineering Structures, vol. 30, pp. 28182829, 2008.

[8] C. Karayannis, M. Favvata, "Earthquake-induced interaction between adjacent reinforced concrete structures with non-equal heights", Earthquake Engineering \& Structural Dynamics, vol. 34(1), pp.1-20, 2005.

[9] C. Karayannis, M. Favvata, "Inter-story pounding between multistory reinforced concrete structures", Structural Engineering and Mechanics, vol. 20(5), pp. 505-526, 2005.

[10] S. Abdel Raheem, "Mitigation measures for earthquake induced pounding effects on seismic performance of adjacent buildings", Bulletin of Earthquake Engineering, vol. 12, pp. 1705-1724, 2014.

[11] S. Abdel Raheem, M. Fooly, A. Abdel Shafy, Y. Abbas, M. Omar, M. Abdel Latif, S. Mahmoud, "Seismic pounding effects on adjacent buildings in series with different alignment configurations", Steel and Composite Structures, vol. 28(3), pp. 289-308, 2018. 
[12] S. Abdel Raheem, M. Fooly, A. Abdel Shafy, A. Taha, Y. Abbas, M. Abdel Latif, "Numerical simulation of potential seismic pounding among adjacent buildings in series", Bulletin of Earthquake Engineering, vol. 17, pp. 439-471, 2019.

[13] N. Mate, S. Bakre, and O. Jaiswal, "Seismic Pounding of Adjacent Linear Elastic Buildings with Various Contact Mechanisms for Impact Simulation," Asian Journal of Civil Engineering (BHRC), vol. 16(3), pp. 383-415, 2015.

[14] H. Elwardany, A. Seleemah, R. Jankowski, "Seismic pounding behavior of multi-story buildings in series considering the effect of infill panels", Engineering Structures, vol. 144, pp. 139-150, 2017.

[15] H. Naderpour, S. Khatami, R. C. Barros, "Prediction of Critical Distance Between Two MDOF Systems Subjected to Seismic Excitation in Terms of Artificial Neural Networks", Periodica Polytechnica Civil Engineering, vol. 61(3), pp. 516-529, 2017.

[16] S. M. Khatami, H. Naderpour, R. C. Barros, R. Jankowski, "Verification of Formulas for Periods of Adjacent Buildings Used to Assess Minimum Separation Gap Preventing Structural Pounding during Earthquakes", Advances in Civil Engineering, Hindawi, https://doi.org/10.1155/2019/9714939, Article ID 9714939, 8 pages, 2019.

[17] S. Khatami, H. Naderpour, S. Razavi, R. Barros, A. Jakubczyk-Gałczyńska, R. Jankowski, "Study on Methods to Control Interstory Deflections", Geosciences, vol. 10(2), 75, 2020.

[18] MATLAB, 9.6.0.1072779 (R2019a), Natick, Massachusetts, USA: The MathWorks, Inc.

[19] CSI, "SAP2000 - Modeling and calculation of structures through finite elements - Structural Analysis Program," Computers \& Structures Inc., Berkeley, California.

[20] R. Jankowski, and S. Mahmoud, EarthquakeInduced Structural Pounding, Switzerland: Springer, 2015.

[21] J. W. S. Rayleigh, Theory of Sound, Vol. 1, New York, USA: Dover, 1945.

[22] European Committee for Standardization (ECS), Eurocode 2 (EC2), EN1992-1-1: Design of concrete structures - Part 1-1: General rules and rules for buildings, Brussels, Belgium, 2004.
[23] European Committee for Standardization (ECS), Eurocode 8 (EC8): Design of structures for earthquake resistance - Part 1: General rules, seismic actions and rules for buildings (EN 1998-1), Brussels, Belgium, 2004.

[24] Pacific Earthquake Engineering Research Center (PEER) strong ground motion data base. Available online:https://peer.berkeley.edu/peerstrong-ground-motion-databases.

[25] Seismosoft (2021). SeismoMatch version 2021. Available online: http://www.seismosoft.com.

[26] S. Anagnostopoulos, "Equivalent viscous damping for modeling inelastic impacts in earthquake pounding problems," Earthquake Engineering and Structural Dynamics, vol. 33, pp. 897-902, 2004.

[27] P. Komodromos, P. Polycarpou, L. Papaloizo, e M. Phocas, "Response of seismically isolated buildings considering poundings," Earthquake Engineering and Structural Dynamics, vol. 36, pp. 1605-1622, 2007.

[28] R. Jankowski, "Experimental study on earthquake-induced pounding between structural elements made of different building materials," Earthquake Engineering and Structural Dynamics, vol. 39, pp. 349-354, 2010.

[29] S. Anagnostopoulos, "Pounding of buildings in series during earthquakes," Earthquake Engineering and Structural Dynamics, vol. 16, pp. 443-456, 1988.

\section{Acknowledgements}

This paper is within the scope of the first author's $\mathrm{Ph} . \mathrm{D}$. degree in progress, financially supported by the Portuguese Foundation for Science and Technology (FCT) through the $\mathrm{PhD}$ grant reference SFRH/BD/139570/2018 under the programme POCH (N2020 - P2020) and subsidized by the European Social Fund (FSE) and national funds from MCTES. This work was financially supported by: Base Funding - UIDB/04708/2020 of the CONSTRUCT - Instituto de I\&D em Estruturas e Construções - funded by national funds through the FCT/MCTES (PIDDAC).

\section{Creative Commons Attribution License 4.0 (Attribution 4.0 International, CC BY 4.0)}

This article is published under the terms of the Creative Commons Attribution License 4.0 https://creativecommons.org/licenses/by/4.0/deed.en US 